Tropical Journal of Applied Natural Sciences
Trop. J. Appl. Nat. Sci., 2(1): 46-53 (2017)
ISSN: 2449-2043
https://doi.org/10.25240/TJANS.2017.2.1.08

\title{
Effects of Cassava (Manihot esculenta Crantz) Effluents on Macroinvertebrate Assemblages in a Rainforest Lotic Freshwater Ecosystem, Southern Nigeria
}

\author{
Ibemenuga, Keziah Nwamaka*, Nzekwe, Obinna Innocent \\ Department of Biological Sciences, Chukwuemeka Odumegwu Ojukwu University, Anambra State, Nigeria \\ *Corresponding author's email: jesusvesselofhonour@yahoo.com; +234(0)8126421299
}

\begin{abstract}
Cassava effluents reduce water quality and destroy aquatic life. Investigations into the effect of cassava effluents on macroinvertebrate assemblages in rainforest lotic freshwater ecosystem, southern Nigeria was conducted between July and December 2015. Three sampling stations were studied. While station I lies upstream, stations II and III lie middle and downstream respectively. Water and macroinvertebrate samples were collected from the study stations. The physicochemical properties of water samples was ascertained following standard procedures. The low dissolved oxygen of $2.32 \pm 0.24 \mathrm{mg} / \mathrm{l}$ obtained in station II was due to the breakdown of cassava waste by microorganisms. The highest mean values of biochemical oxygen demand, $\mathrm{pH}$, nitrate-nitrogen and phosphatephosphorus were recorded in station II. A total of 6 classes of macroinvertebrates composed of 10 orders, 17 families, 22 species and 357 individuals was recorded in the study. Insecta was the most abundant class. Plesiopora was the most abundant order while Arcynchobdellida was the least order $(6,1.7 \%)$. Dero $s p$. was the most abundant species of oligochaete population. Sensitive macroinvertebrates such as coleopterans, dipterans and ephimeropterans were absent in station II. The low macroinvertebrate population encountered in station II is attributed to the untreated cassava effluent discharged into it. Treating cassava effluents before disposal and siting of cassava based starch/garri processing mills away from water bodies are among control measures recommended to prevent destruction of aquatic macroinvertebrates and distortion of water quality.
\end{abstract}

\section{INTRODUCTION}

$\mathrm{T}$ There has been increasing pollution of water bodies in Nigeria from anthropogenic activities. This has caused deterioration in water qualities. Wade et al. (2002), Walsh et al. (2002) and Arimoro and Osakwe (2006) listed anthropogenic activities to include release or discharge of agricultural waste from agro-allied industries, refineries, human and animal waste, laundering, car washing and wood waste.

Cassava (Manihot esculenta Crantz) is a staple food in most developing countries. The shrub of Euphorbiaceae (Ehiagbonare et al., 2009) is extensively cultivated in the tropical and subtropical regions of the world and grows to edible starchy tuberous roots with more than 200 calories/day of food value (FAO, 2004). In sub-saharan Africa (SSA) cassava is currently the major staple food for $40 \%$ of the population and for an estimated 500 million people in the tropics (Dufour, 1989; Okafor, 2004; Burns et al., 2010; Okunade and Adekalu, 2013).

Wastewater is usually generated in different ways such as during washing, moisture grating, extraction through pressing, as well as processing cassava tubers into food, feed, starch and other products. Most cassava processing industry discharges significant quantities of wastewater whose major component is cyanide to rivers, lakes, sewage canals which eventually flows back to streams or downstream surface water locations (Oliveira et al., 2001). Cassava contains cyanide which is toxic. Studies on toxic effects of cyanide on aquatic life include Yang et al., (1994), Okafor (1998), Wade et al. (2002), Oboh (2004), Abiona et al. (2005) and Ehiagbonare et al. (2009). Hydrocyanic acid (HCN) resulting 
from the processing of cassava tubers may lead to death of fish and other aquatic organisms (Oti, 2002; Oboh and Akindahunsi, 2003; Oboh, 2004). Suspended solids of effluents may settle on a stream bed and spoil fish breeding grounds (Arimoro et al., 2008). Discharge of cassava effluents has become serious problems that pose threat to aquatic environment and its life forms. The aim of the present study is to determine the effects of cassava effluents on environmental variables and macroinvertebrate communities in the water body.

\section{MATERIALS AND METHODS}

The Amaku Stream (Figure 1) is a perennial stream situated in the rainforest belt of southern Nigeria. The stream lies between longitude $06^{\circ} 49^{\prime} 08^{\prime \prime}, 06^{\circ} 54^{\prime} 08^{\prime \prime} \mathrm{E}$ and latitude $05^{\circ}$ $49^{\prime} 20^{\prime \prime}, 05^{\circ} 53^{\prime} 20^{\prime \prime} \mathrm{N}$. It rises from Ndiogboro village in Ihiala town, flows in North east direction and empties into Atamiri Stream in Umuezeawara Ihiala, Ihiala Local Government Area. The climate of the study area shows distinct rainy (April - September) and dry (October - March) seasons. The area is characterized by sloppy land surface.
Three study stations were investigated. Station I lies upstream with the estimate terrain elevation of 16 meters above sea level. Little or no human activities occur in this station. The water in this station is clear. The station is exposed to sunlight. Aquatic macriophytes growing along stream margin include Aeroceras sp and Echnochoa pyramidalis.

Station II, the middle stream receives cassava effluent discharge from Nigerian Starch Mills Limited: the Home of Cassava Starch Uli. It is shallow with an estimate elevation of 15.5 meters above sea level. Serious human activities such as laundry, washing of cassava and breadfruit occur in this station. Macrophytes in this station include Eichhornia crassipes, Costus afar and Aeroceras sp.

Station III, the downstream, had the estimate terrain elevation of 14 meters above sea level. The main human activity in this station is washing of motor cycles. It is densely populated with aquatic macrophytes such as Eichhornia crassipes and Aeroceras sp.

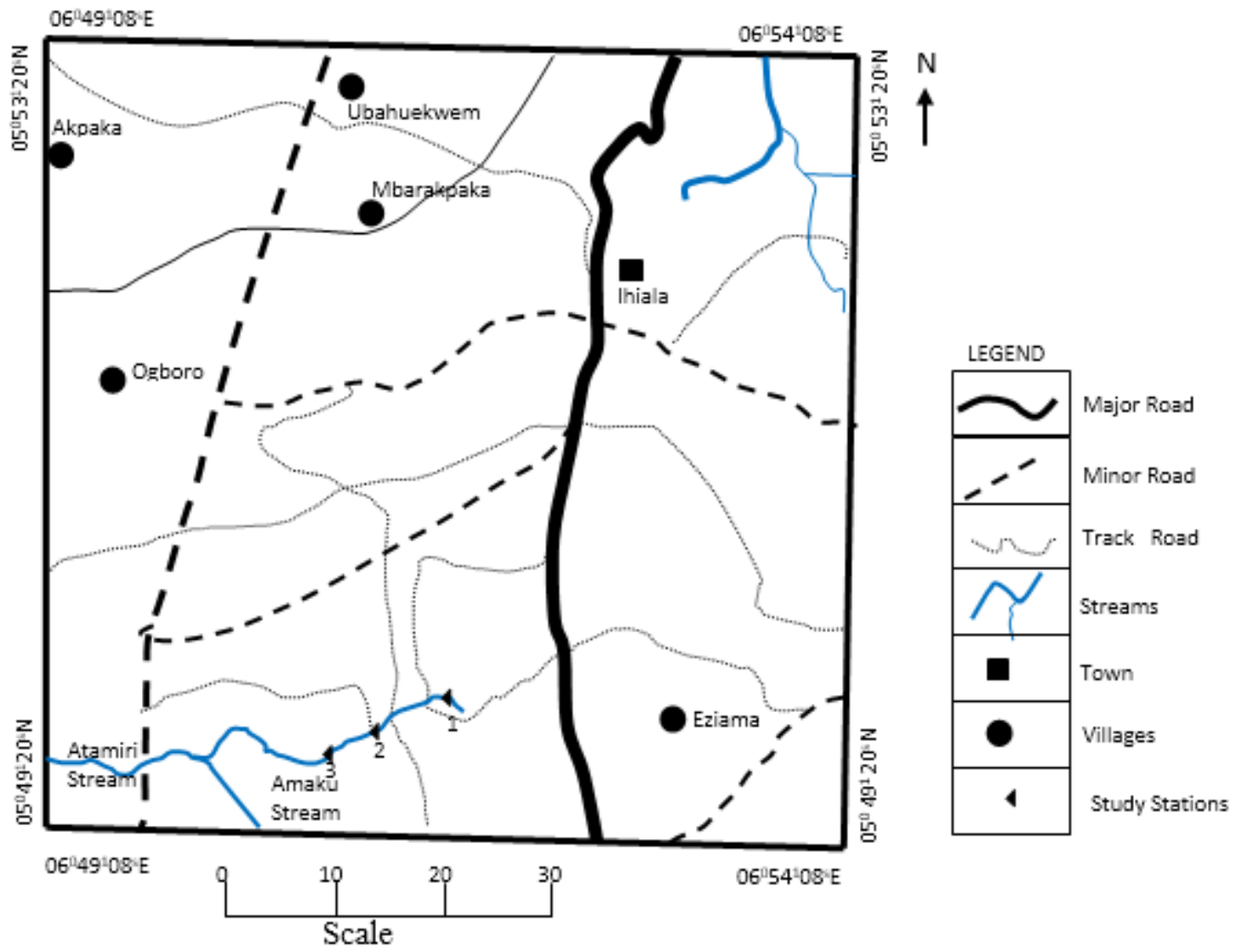

Figure 1: Map of the Study Area.

\section{Water Quality Analysis}

Water samples for water quality characteristics were collected fortnightly in the three sampling stations for six months (July to December 2015), covering the dry and rainy seasons. The physico-chemical parameters were determined. Air and

water temperature were measured using thermometer, depth was determined using a calibrated meter tape and straight wooden pole which was fixed at a particular point till it touches the substratum. Water velocity was measured using floatation method. Conductivity was determined using conductivity meter (Labtech Model 280). pH was determined using Griffin battery operated $\mathrm{pH}$ meter (Model PHS-3B). Turbidity was determined with turbidity meter (Model P2VH8 England). Nitrate-nitrogen was determined using spectrophotometric 20 (Model PHS-25-Techmel USA). Dissolved oxygen, biochemical oxygen demand, alkalinity 
and phosphate-phosphorus were determined titrimetrically according to APHA (1998).

\section{Sampling Technique}

Samples of macroinvertebrates were collected from the study stations using sieve and serrated core sampler. Rocks, mud, sand and gravel bottoms were sampled using kick and sweep technique. Shoreline vegetation were swept with a net to collect adult insects. Collected mud and debris in bucket were sieved using sieves. Macroinvertebrates present were emptied into white tray containing little water. Using forcepts the specimens were picked into containers labeled according to stations. They were preserved in $10 \%$ formalin and transported to laboratory for identification using keys of Thorp and Rogers (2011) and Egborge (1993). Community structure and faunal similarities were analyzed using Margalef taxa richness, diversity, evenness and dominance.

\section{Data Analysis}

Statistical computations were carried out using the SPSS 16.0 for windows. Analysis of variance (ANOVA) was used to compare macroinvertebrate community attributes of the study stations. Community structure was analyzed using the methods of Ogbeibu (2005). Hutcheson's t-test adopted from Magurran (1988) was used to test significant differences between general diversity indices among the study stations.
McNemar's test according to Ogbeibu (2005) was used for comparing similarities between stations.

\section{RESULTS}

\section{Physico-chemical parameters}

The results of the physico-chemical characteristics of the study stations is presented in Table 1 . Both air and water temperature were highest in station I and lowest in station II with respective mean value of $29.41 \pm 0.39^{\circ} \mathrm{C}$ and $28.25 \pm 0.12^{\circ} \mathrm{C}$. Air temperature differed significantly $(p<0.05)$ among the study stations. Water temperature was not significantly different $(\mathrm{p}>0.05)$ at the study stations. Dissolved oxygen mean value obtained during the study was maximum at station I $(6.53 \pm 0.25 \mathrm{mg} / \mathrm{l})$ followed by station III $(4.55 \pm 0.15 \mathrm{mg} / \mathrm{l})$. The least value was recorded at station II $(2.32 \pm 0.24 \mathrm{mg} / \mathrm{l})$. These values were significantly different $(\mathrm{p}<0.05)$ at the study stations.

Water current which varied significantly at the stations was highest in station III $(0.31 \pm 0.18 \mathrm{~m} / \mathrm{s})$. The mean values of biochemical oxygen demand, turbidity, alkalinity and nitrate-nitrogen which were maximum in station II and minimum in station I differed significantly $(\mathrm{p}<0.05)$ at the study stations. $\mathrm{pH}$ had its highest value $(5.64 \pm 0.12)$ in station I and lowest value $(5.15 \pm 0.05)$ in station II. Phosphate-phosphorus was highest in station II and lowest in station III.

Table 1: Physico-chemical characteristics of sampling stations

\begin{tabular}{|c|c|c|c|c|}
\hline Parameter & Station I & Station II & Station III & Significance \\
\hline Air temperature $\left({ }^{\circ} \mathrm{C}\right)$ & $29.41 \pm 0.39$ & $27.35 \pm 0.52$ & $26.51 \pm 0.04$ & $\mathrm{p}<0.05^{*}$ \\
\hline Water temperature $\left({ }^{\circ} \mathrm{C}\right)$ & $28.25 \pm 0.12$ & $27.15 \pm 0.46$ & $26.12 \pm 0.35$ & $\mathrm{p}>0.05$ \\
\hline Depth $(\mathrm{m})$ & $0.78 \pm 0.08$ & $0.54 \pm 0.15$ & $0.63 \pm 0.13$ & $\mathrm{p}>0.05$ \\
\hline Current $(\mathrm{m} / \mathrm{s})$ & $0.08 \pm 0.13$ & $0.23 \pm 0.12$ & $0.31 \pm 0.18$ & $\mathrm{P}<0.05^{*}$ \\
\hline Dissolved oxygen $(\mathrm{mg} / \mathrm{l})$ & $6.53 \pm 0.25$ & $2.32 \pm 0.24$ & $4.55 \pm 0.15$ & $\mathrm{P}<0.05^{*}$ \\
\hline Turbidity (NTU) & $0.21 \pm 0.09$ & $0.55 \pm 0.18$ & $0.35 \pm 0.13$ & $\mathrm{P}<0.05^{*}$ \\
\hline $\mathrm{pH}$ & $5.64 \pm 0.12$ & $5.15 \pm 0.05$ & $6.52 \pm 0.07$ & $\mathrm{p}>0.05$ \\
\hline Alkalinity (mg/l) & $7.65 \pm 3.18$ & $21.13 \pm 2.13$ & $9.22 \pm 2.61$ & $\mathrm{P}<0.05^{*}$ \\
\hline $\begin{array}{l}\text { Biochemical oxygen demand } \\
(\mathrm{mg} / \mathrm{l})\end{array}$ & $2.35 \pm 0.03$ & $8.75 \pm 0.17$ & $3.41 \pm 0.21$ & $\mathrm{p}<0.05^{*}$ \\
\hline Nitrate-nitrogen $(\mathrm{mg} / \mathrm{l})$ & $0.98 \pm 0.51$ & $1.67 \pm 0.42$ & $1.37 \pm 0.28$ & $\mathrm{P}<0.05 *$ \\
\hline Phosphate-phosphorus (mg/l) & $0.31 \pm 0.23$ & $0.48 \pm 0.27$ & $0.18 \pm 0.06$ & $\mathrm{p}>0.05$ \\
\hline
\end{tabular}

$*$ = significant difference $(\mathrm{p}<0.05)$

\section{Composition and abundance of macroinvertebrates from the study stations, Amaku Stream}

Six (6) classes of macroinvertebrates composed of ten (10) orders, seventeen (17) families, twenty-two (22) species and 357 individuals were recorded in this study (Table 2). The percentage abundance of macroinvertebrates in the study stations is shown in Figure 2. The highest percentage abundance was recorded in station I (44.5\%), followed by station III (35.0\%). The abundance was lowest in station II (20.4\%). A priori test for multiple comparison showed that station II was the cause of the observed differences. 
Table 2: Macroinvertebrate composition, abundance and distribution along the study stations

\begin{tabular}{|c|c|c|c|c|c|c|}
\hline \multirow[b]{2}{*}{ Class } & \multirow[b]{2}{*}{ Order } & \multirow[b]{2}{*}{ Family } & \multirow[b]{2}{*}{ Species } & \multicolumn{3}{|c|}{ Stations } \\
\hline & & & & I & II & III \\
\hline \multirow[t]{14}{*}{ Insecta } & Odonata & Coenagrionidae & Coenagrion puella & 2 & 3 & 3 \\
\hline & & Libellulidae & Enallagma sp. & 3 & 4 & 15 \\
\hline & & & Sympetrum sp. & 10 & 6 & 5 \\
\hline & & & Tetragoneuria $\mathrm{sp}$ & 3 & 2 & 1 \\
\hline & Hemiptera & Naucoridae & Naucoris cimicoides & 3 & - & - \\
\hline & & Nepidae & Ranatra fusca & 5 & 2 & 7 \\
\hline & & Veliidae & Velia caprai & 7 & - & 6 \\
\hline & & Gerridae & Gerris lacustris & 5 & 3 & - \\
\hline & Coleoptera & Dytiscidae & Dytiscus sp. & 9 & - & - \\
\hline & & Gyrinidae & Gyrinus sp. & 11 & - & 2 \\
\hline & Diptera & Simulidae & Simulium sp. & 5 & - & 12 \\
\hline & & Tipulidae & Tipula augustipinnis & 10 & - & 13 \\
\hline & Ephemeroptera & Baetidae & Baetis sp. & 4 & - & 1 \\
\hline & & & Cleon sp. & 8 & - & 1 \\
\hline \multirow[t]{2}{*}{ Crustacea } & Decapoda & Palaemonidae & Macrobrachium rosenbergii & 4 & 1 & 3 \\
\hline & & & Macrobrachium sp & 6 & 1 & 9 \\
\hline \multirow[t]{2}{*}{ Arachnida } & Araneae & Dolomedidae & Dolomedes fimbriatus & 3 & 4 & 3 \\
\hline & & Agronectidae & Agronecta aquatica & 12 & 7 & 15 \\
\hline \multirow[t]{2}{*}{ Oligochaeta } & Plesiopora & Naididae & Dero sp. & 29 & 19 & 18 \\
\hline & & & Nais $s p$. & - & 15 & - \\
\hline Hirudinea & Arhynchobdellida & Hirudinidae & Hirudo sp. & - & 6 & - \\
\hline Gastropoda & Hydrophila & Limnaeidae & Limnaea sp. & 20 & - & 11 \\
\hline Total & & & & 159 & 73 & 125 \\
\hline No. of individuals & & & & 20 & 13 & 17 \\
\hline
\end{tabular}

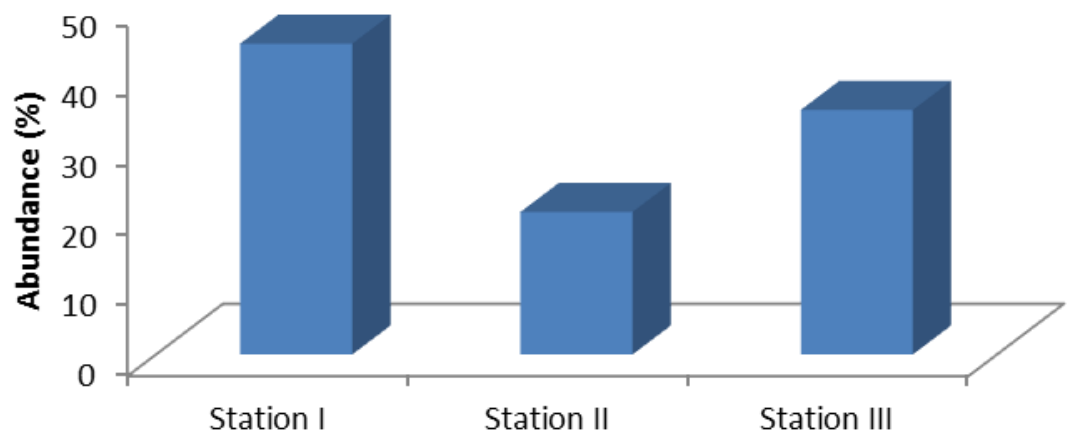

Figure 2: Abundance of macroinvertebrates at study stations.

The abundance of major taxonomic groups of macroinvertebrates recorded in the study showed that Insecta $(47.90 \%)$ was the dominant class and Hirudinea (1.68\%)was the least class (Figure 3). Plesiopora (Oligochaeta) (22.69\%) formed the largest order accounting for the maximum number of individuals (Figure 4). Arhynchobdellida (1.68\%) was the least abundant order. Dero sp., the most abundant species of the oligochaete population dominated the samples in the study stations. It is the most dominant macroinvertebrate in all the study stations. Oligochaetes were most abundant in station II. Arhynchobdellida represented by Hirudo sp showed restricted distribution occurring only in station II. Gastropoda represented by Limnaea sp. was absent in station II. Crustaceans comprising Macrobrachium rosenbergii and Macrobrachium sp. of the family Palaemonidae occurred more in stations I and III respectively with least and equal abundance in station II. Two taxa Dolomedes fimbriatus (Dolomedidae) and Agronecta aquatica (Agronectidae) comprised the order Araneae. Both were ubiquitous in distribution. Odonatans were represented by three families. The family Coenagroindae represented by Coenagrion puella and the family Tetragoneuridae represented by Tetragoneuria sp. were ubiquitous occurring in all the stations. The family Libellulidae represented by Enallagma sp. and Symptetrum $\mathrm{sp}$. occurred in all the study stations. Hemipterans were represented by four families. The family Naucoridae comprising Naucoris cimicoides, the family veliidae comprising Velia caprai and the family Gerridae comprising Gerris lacustris showed restricted distribution being recorded in station I, stations II and III, and stations I and II respectively. The family Nepidae comprising Ranatra fusca occurred in stations I, II and III. The order Coleoptera was represented by two families namely Dytiscidae and Gyrinidae. Their representative taxa namely Dytiscus sp. and Gyrinus sp. were restricted in distribution. Diptera was represented by two taxa namely Simulium sp. (Simulidae) and Tipula augustipinnis (Tipulidae) which were absent in station II. Ephemeroptera was represented by two taxa comprising Baetis sp. and Cleon sp. which were absent in station II. 


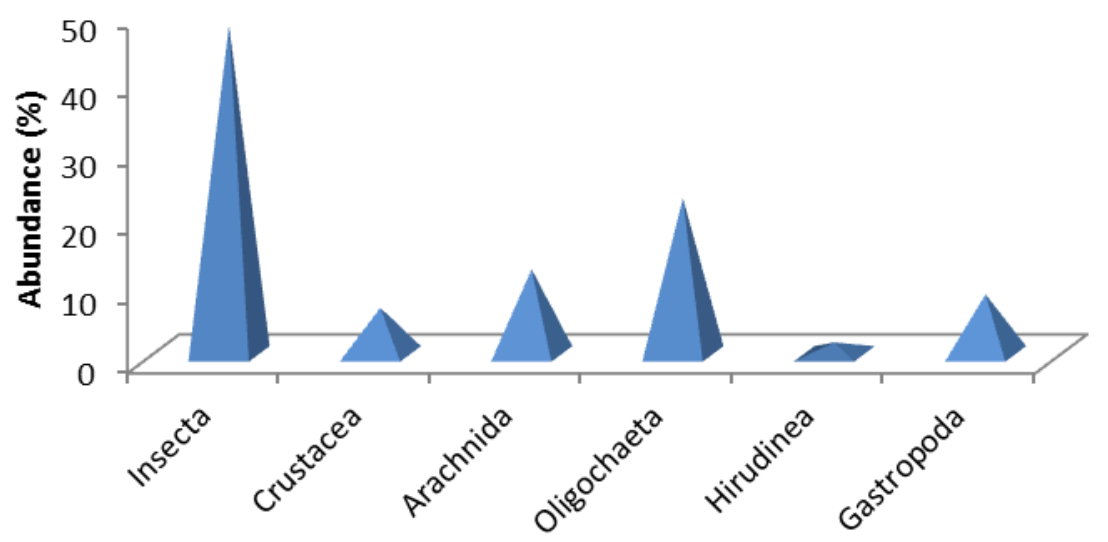

Figure 3: Class abundance of macroinvertebrates in Amaku Stream.

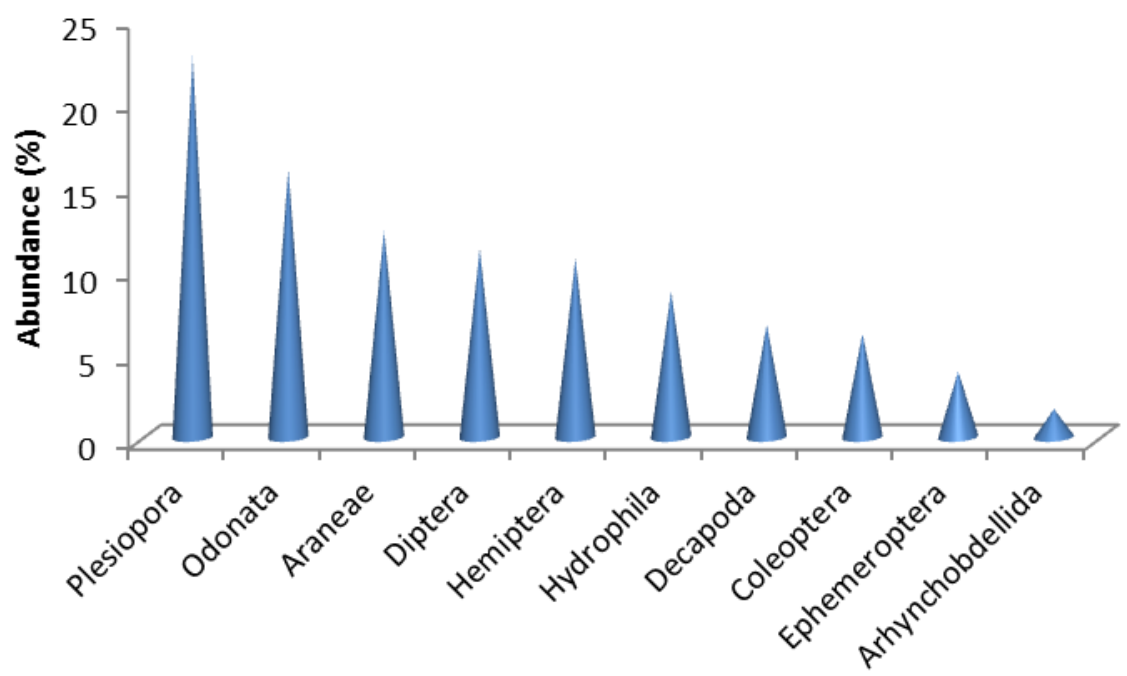

Figure 4: Order of macroinvertebrates in Amaku Stream.

\section{Diversity and Dominance}

Some diversity indices of macroinvertebrate species in the three study stations is shown in Table 3. Margalef's species richness (d) which depicts taxa richness was highest in station I (3.945), followed by station III (3.313). Station II had the minimum taxa richness (2.797), diversity (0.958) and evenness (0.860) indices and the maximum dominance index (0.145).

Hutcheson's t-test was performed to compare diversity indices between the study stations. The results obtained showed that the stations were significantly different $(\mathrm{p}<0.05)$ (Table 4). Significant difference $(\mathrm{p}<0.05)$ also existed between stations I and III, and stations II and III.

Table 3: Diversity of macroinvertebrates in the study stations

\begin{tabular}{llll}
\hline Diversity of macroinvertebrate species & Station I & Station II & Station III \\
\hline No. of individuals & 159 & 73 & 125 \\
No. of taxa & 20 & 13 & 17 \\
Margalef's taxa richness (d) & 3.945 & 2.797 & 3.313 \\
Diversity (Shannon-Wiener index) (H) & 1.156 & 0.958 & 1.102 \\
Evenness (E) & 1.025 & 0.860 & 0.896 \\
Dominance (C) & 0.078 & 0.145 & 0.092 \\
\hline
\end{tabular}


Table 4: Hutcheson's t-test of general diversity indices between pairs of stations

\begin{tabular}{|c|c|c|c|}
\hline & Station I & Station II & Station III \\
\hline Station I & & $\mathrm{S}^{*}$ & $\mathrm{~S}$ \\
\hline Station II & & & $S$ \\
\hline Station III & & & \\
\hline
\end{tabular}

\section{Faunal similarity of study stations}

Faunal similarities of study stations was evaluated using McNemar's test and the results are shown in Table 5. The paired similarity test revealed close similarity between stations I and II, and stations II and III.

Table 5: Similarity coefficients for pairs of study stations

\begin{tabular}{llll}
\hline & Station I & Station II & Station III \\
\hline Station I & & $12.5^{*}$ & 1.333 \\
Station II & & 4.444 \\
Station III & & &
\end{tabular}

*Significant difference $(\mathrm{p}<0.05)$

\section{DISCUSSION}

The variations in the physico-chemical parameters of Amaku Stream could be attributed to cassava effluent. Generally air temperature was higher than water temperature. The mean air and water temperature values recorded in this study are typical of the African tropical Rivers (Imoobe and Oboh, 2003; Arimoro et al., 2008). The high temperature obtained in station I may be due to its exposure to sunlight. The low temperature recorded in station III may be attributed to its being covered by aquatic macrophytes which cuts off most of the sunlight. Aquatic plants form a heavy shading canopy that reduces light penetration. This shading with reduced water circulation in dense plant stands allows the formation of vertical temperature gradients as steep as $18^{\circ} \mathrm{F}\left(10^{\circ} \mathrm{C}\right)$ over $3 \mathrm{ft}(1 \mathrm{~m})$ of water (UF/IFAS, 2007). The low dissolved oxygen $2.32 \pm 0.24 \mathrm{mg} / \mathrm{l}$ obtained in station II was caused by anthropogenic activities such as discharge of cassava effluents. The very low oxygen observed at station II was due to the breakdown of cassava wastes by micro-organisms. Arimoro et al. (2008) reported a depletion of dissolved oxygen in their studies. The permissible dissolved oxygen limit for aerated water body by World Health Organization is 5.0 - $6.0 \mathrm{mg} / \mathrm{l}$ (Oluyemi et al., 2010; Anigboro et al., 2014). Biochemical oxygen demand values indicate the extent of organic pollution in water quality (Jonnalagadda and Mhere, 2001). The biochemical value of $8.75 \pm 017 \mathrm{mg} / \mathrm{l}$ obtained in station II indicated the extent of stress this station is undergoing presently. Streams are classified into: unpolluted (BODs $<1.0 \mathrm{~m} \mathrm{~g} / \mathrm{l}$ ), moderately polluted (BODs, between $2-$ $9 \mathrm{mg} / \mathrm{l}$ ) and heavily polluted streams (BODs $>10.0 \mathrm{mg} / \mathrm{l}$ ) (modified from Adakole and Anunne, 2003; Arimoro et al., 2008). Thus Amaku Stream is moderately polluted. The biochemical oxygen demand was higher than the EEC limits of $4.0 \mathrm{mg} / \mathrm{l}$ (Umeham et al., 2007). Biochemical oxygen demand is a major index for measuring pollution stress, so the recorded high value classifies the stream as poor drinking water source. The high nitrate-nitrogen recorded in station II could be attributed to the cassava effluent disposed into it. The discharge of effluent into "well" and/or spreading on land leads to higher nitrate on the streams as well as a highly offensive odour in the environment (Afuye and Mogaji, 2015). The minimum $\mathrm{pH}$ value in station II could be attributed to cassava effluent discharged into it. Cassava contains hydrocyanic acid which is a very weak acid. Water bodies receiving untreated cassava water are usually reported to be highly acidic, sometimes with pH as low as 2.6 (Zualiya and Muzondo, 1993; Arimoro et al., 2007; Atulegwu and Nnamdi, 2011). Cassava are known to spoil streambeds by the settled suspended solid of the effluent, thereby making marine lives and fish breeding pretty difficult to survive (Zualiya and Muzondo, 1993; Yang et al., 1994; Wade et al., 2002; Abiona et al., 2005; Atulegwu and Nnamdi, 2011).

The 22 taxa of macroinvertebrates recorded in this study is lower than 46 taxa reported by Edokpayi et al. (2000), 62 taxa obtained by Egborge et al. (2003) and 55 taxa reported by Arimoro et al. (2008) in some troubled freshwater ecosystems of Nigeria. The abundance of oligochaetes in station II may be attributed to cassava effluents discharged into it. The least abundance of crustaceans in station II could be due to environmental stress this station is experiencing. The absence of Limnaea sp. in station II may be attributed to the presence of Hirudinea sp. which were favoured by organic matter. The Hirudinea sp. are among the external parasites of snails. Cassava effluent probably caused disruption of the life cycle, reproductive cycle, food chain, and migrations or imposed physiological stress (Arimoro et al., 2008). This also explains the complete absence from station II of benthic macroinvertebrates such as Dytiscus sp., Gyrinus sp. (coleopterans) as well as Baetis sp. and Cleon sp. (ephemeropterans) associated with clean water. These species were among very sensitive species reported by Ibemenuga and Nwosu (2012).

The ecological indices in Table 3 revealed the decimating impact of cassava effluents on macroinvertebrate residents of Amaku Stream. Reduced values of taxa richness, ShannonWiener diversity, evenness indices and the increased dominance index at station II are similar to the typical response of macroinvertebrate communities to organic pollution (Walsh et al., 2002; Ndaruga et al., 2004; Atobatele et al., 2005; Arimoro et al., 2007; Arimo et al., 2008). 
This study showed that untreated cassava effluents discharged into Amaku Stream disturbed water quality and distribution of sensitive species. Several wastes are generated from the processing of cassava into fufu, starch and garri. Continuous discharge of these wastes has accentuated the adverse effect of cassava waste to the environment and biodiversities (Goodley, 2004; Atulegwu and Nnamdi, 2011). Apart from high cyanide contents, the discharge of effluent directly (Afuye and Magaji, 2015) into streams cause foul smell and produces unattractive sights (FAO and IFAD, 2001; Afuye and Magaji, 2015).

\section{CONCLUSIONS}

Cassava effluent discharged into Amaku Stream altered its physico-chemical conditions especially in station II. Thus dissolved oxygen was least in this station while turbidity, biochemical oxygen demand, alkalinity and nitrate-nitrogen were maximum in station II. This resulted in low macroinvertebrate abundance in this station.

\section{RECOMMENDATIONS}

Since cassava effluents distort water quality, and destroy sensitive macroinvertebrate species, it is recommended that:

i.. Cassava effluents should be treated before disposal into aquatic environment;

ii. Cassava based starch/garri processing mills should be located away from aquatic environments;

iii. Cassava wastes could be broken down by subjecting them to high voltage electricity industries.

\section{REFERENCES}

Abiona, O.O., Sanni, L. and Banbgose, O. (2005). An evaluation of microbial load, heavy metals and cyanide contents of water sources, effluents and peels from cassava processing locations. Journal of Food and Agricultural and Environment, 3(1): 207-208.

Adakole, J.A. and Anunne, P.A. (2003). Benthic macroinvertebrates as indicators of environmental pollution. Journal of Aquatic Sciences, 18(2): 85-92.

Afunye, G.G. and Mogaji, K.O. (2015). Effect of cassava effluents on domestic consumption of shallow well water in Owo Local Government Area, Ondo State, Nigeria. Physical Sciences Research International, 3(3): 37-43.

American Public Health Association (APHA) (1998). Standard Methods for the Examination of Water and Waste Water 20th Edition, Washington, DC, USA.

Anigboro, F.O., Nwadukwe, F.O. and Arimoro, F.O. (2014). Fish community structure in Iye-Ekpen Stream, Delta State, Southern Nigeria. Journal of Applied Sciences, 29(2A): 247-255.

Arimoro, F.O. and Osakwe, E.I. (2006). The influence of sawmill wood wastes on the distribution and population of macroinvertebrates at Benin River, Niger Delta Area, Nigeria. Chemistry and Biodiversity, 3: 578-592.

Arimoro, F.O., Ikomi, R.B. and Iwegbue, C.M.A. (2007). Ecology and abundance of oligochaetes as indicators of organic pollution in an urban stream in southern Nigeria. Pakistan of Biological Science, 10(3): 446-453.
Arimoro, F.O., Iwegbue, C.M.A. and Enemudo, B.O. (2008). Effects of cassava effluent on benthic macroinvertebrate assemblages in a tropical stream in southern Nigeria.

Atobatele, O.E., Morenikeji, O.A. and Ugwumba, A.O. (2005). Spatial variation in physical and chemical parameters of benthic macroinvertebrate fauna of River Ogunpa, Ibadan. The Zoologist, 3: 58-67.

Atulegwu, P.U. and Nnamdi, E. (2011). Quality Assessment of the Cassava-Mill-Effluent polluted Entric-Tropofluvent Soil. Research Journal of Environmental Sciences, 5: 342-353.

Burns, A., Gleadow, R., Cliff, J., Zacarias, A. and Cavagnaro, T. (2010). Cassava: The drought, war and famine crop in a changing world. Sustainability, 2(11): 3572-3607.

Dufour, D.L. (1989). Effectiveness of cassava detoxication techniques used by indigenous peoples in the Northwest Amazonia. Interciencia, 14(2): 86-91.

Edokpayi, C.A., Okenyi, A.E., Ogbeibu, A.E. and Osimen, E.C. (2000). The effect of human activities on the macrobenthic invertebrates of Ibiekuma Stream, Ekpoma, Nigeria. Bioscience Research Communications, 12: 7987.

Egborge, A.B.M. (1993). Biodiversity of Aquatic Fauna in Nigeria. National Resources Conservation Council, Abuja. 173pp.

Egborge, A.B.M., Ezemonye, L.I. and Awoze, G.E. (2003). Macroinvertebrate fauna of Udu-Ughievwen Wetlands, Southern Nigeria. Journal of Aquatic Sciences, 18(1): $1-8$.

Ehiagbonare, J.E., Adjarhore, R.Y. and Enabulele, S.A. (2009). Effect of cassava effluent on Okada natural water. African Journal of Biotechnology, 8(12): 2816-2818.

Food and Agricultural Organization (FAO) (2004). Strategic Environmental
http://www.fao.org.//docrep/4/17/2006

Food and Agricultural Organization (FAO) and International Fund for Agricultural Development (IFAD) (2001). Strategic environmental assessment: An assessment of the impact of cassava production and processing on the environment and biodiversity. Proceedings of the Validation Forum of the Global Cassava Development Strategy, April 10-12, Rome, Italy, Pp. 45-45.

Goodley, J. (2004). A compendium DHI-water and Environment. $4^{\text {th }}$ ed. http://www.fao.org.12/14/2005.

Ibemenuga, K.N. and Nwosu, M.C. (2012). Macroinvertebrates as indicators of water quality of an urban stream in Western region, Sierra Leone. African Science and Technology Journal, 5(2): 1-15.

Imoobe, T.O.T. and Oboh, I.P. (2003). Physical and chemical hydrology of River Jamieson, Niger Delta, Nigeria. Benin Science Digestion, 1: 105-119.

Jonnalagadda, S.B. and Mhere, G. (2001). Water quality of the Odzi River in the eastern highlands of Zimbabwe. Water Research, 35(10): 2371-2376.

Magurran, A. (1988). Ecological Diversity and its Measurements. London, Groom Helm. https://doi.org/10.1007/978-94-015-7358-0.

Ndaruga, A.M., Ndiritu, G.G., Gichuki, N.M. and Wamicha, W.N., (2004). Impact of water quality on the macroinvertebrate assemblages along a tropical stream in Kenya. African Journal of Ecology, 42(3): 208-216.

Oboh, G. (2004). Management of occupational hazards associated with traditional methods of cassava processing in Ogun, Ondo and Oyo States, Nigeria. Proceedings of a Workshop on Promotion of Improved Management Technology Aimed at Reducing Occupational and Environmental Hazards: 11-20. Nigeria: Institute of Agriculture Research Training, Obafemi Awolowo University, Ibadan

Oboh, G. and Akindahunsi, A.A. (2003). Chemical changes in cassava peels fermented with mixed culture of Aspergillus 
niger and two species of Lacobacillus in integrated biosystem. Application in Tropical Agriculture, 8(2): 63-68.

Ogbeibu, A.E. (2001). Distribution, density and diversity of dipterans in a temporary pond in Okomu forest reserve, Southern Nigeria. Journal of Aquatic Sciences, 16: 43-52.

Ogbeibu, A.E. (2005). Biostatistics: A Practical Approach to Research and Data Handling. Mindex Publishing Company Limited, Benin City, 264 pp.

Okafor, E.E. (1998). Acute toxicity of cassava mill effluent to the Africa catfish fingerlings. Journal of Aquatic Sciences, 17(1): 31-34.

Okafor, P.N. (2004). Assessment of cyanide overload in cassava consuming populations of Nigeria and the cyanide content of some cassava based foods. African Journal of biotechnology, 3(7): 358-361.

Okunade, D.A. and Adekalu, D.O. (2013). Physico-chemical Analysis of Contaminated Water Resources Due to Cassava Wastewater Effluent Disposal. European Journal of Science and Technology, 2(6): 75-84.

Oliveira, M.A., Reis, E.M. and Nozaki, J. (2011). Biokenetic parameters investigation for treatment of cassava mill effluents. Water, Air and Soil Pollution, 126(3-4): 307-319.

Oluyemi, E.A., Adekunle, A.S., Adenuga, A.A. and Makinde, W.O. (2010). Physico-chemical properties and heavy metal content of water sources in Ife North Local Government Area of Osun State Nigeria. African Journal of Environmental Science and Technology, 4(10: 691-697.

Osuntokun, B.O. (1994). Chronic cyanide intoxication dietary origin and degenerative neuropathy in Nigerians. Acta Horticulture, 375: 311-321.
Oti, E.E. (2002). Acute toxicity of cassava mill effluent to the African catfish fingerlings. Journal of Aquatic Sciences, (1): $31-34$

Thorp, J.H. and Rogers, D.C. (2011). Field Guide to Freshwater Invertebrates of North America. Academic Press, USA. 274pp.

Umeham, S.N., Okereke, S., Nwaugo, V.O. and Anya, B.C. (2007). Morphometry and Physicochemical hydrology of Igu Stream. International Journal of Biotechnology and Allied Sciences, 2(2): 173-178.

University of Florida/Institute of Food and Agricultural Sciences (UF/IFA Florida LAKEWATCH (2007). A Beginner's Guide to Water Management - Aquatic Plants in Florida Lakes. Circular III. 43pp. http:lakewatrch.ifas.ufl.edu.

Wade, J.W., Omoregie, E. and Ezenwaka, I. (2002). Toxicity of cassava (Manihot esculenta Crantz) effluent on the Nile Tilapia, Oreochromis niloticus (L) under laboratory condition. Journal of Aquatic Sciences, 17(2): 89-94.

Walsh, C., Gooderham, J.P.R., Grace, M.R., Sdraulig, S., Rosyidi, M.I. and Lelone, A. (2002). The relative influence of diffuse and point-source disturbances on a small upland stream in East Java Indonesia: A preliminary investigation. Hydrobiologia, 487: 183-192.

Yang, C.W., Rathinvelu, A., Borowitz, J.I. and Ibom, G.E. (1994). Activation of calcium and $\mathrm{pH}$ dependent phospholipase by cyanide in PC 12 cells. Toxicology and Applied Pharmacology, 24: 262-267.

Zar, J.H. (1984). Biostatical Analysis. 2nd Edition. Prentice Hall, New Jersey. 717pp.

Zualiya, R. and Muzondo, M.I. (1993). Protein enrichment of cassava by solid state fermentation. Labensmitted, 15: 1

\section{How to cite this article}

Ibemenuga, K.N. and Nzekwe, O.I. (2017). Effects of Cassava (Manihot esculenta Crantz) Effluents on Macroinvertebrate Assemblages in a Rainforest Lotic Freshwater Ecosystem, Southern Nigeria. Tropical Journal of Applied Natural Sciences, 2(1): 46-53. Doi: https://doi.org/10.25240/TJANS.2017.2.1.08. 